\title{
Lanthanides Revealing Anthropogenic Impact within a Stratigraphic Sequence
}

\author{
Gianni Gallello, ${ }^{1,2}$ Agustín Pastor, ${ }^{2}$ Agustín Diez, ${ }^{1}$ and Joan Bernabeu ${ }^{1}$ \\ ${ }^{1}$ Department of Prehistory and Archaeology, University of Valencia, 28 Blasco Ibánez Street, 46010 Valencia, Spain \\ ${ }^{2}$ Department of Analytical Chemistry, University of Valencia, 50 Dr. Moliner Street, Burjassot, 46100 Valencia, Spain \\ Correspondence should be addressed to Gianni Gallello; gianga@postal.uv.es
}

Received 21 April 2014; Revised 18 June 2014; Accepted 3 July 2014; Published 16 July 2014

Academic Editor: José Antonio López-Sáez

Copyright (c) 2014 Gianni Gallello et al. This is an open access article distributed under the Creative Commons Attribution License, which permits unrestricted use, distribution, and reproduction in any medium, provided the original work is properly cited.

\begin{abstract}
Difficulties to differentiate between anthropogenic and natural processes in the formation of archaeological deposits are crucial for a correct interpretation not only of the actions involved in the development of archaeological sites, but also of their occupationabandonment dynamics and the understanding of their spatial behaviors and relationship with the environment. We have carried out lanthanides (rare earth elements "REE") analysis to distinguish anthropogenic from natural stratigraphic units in sediments using the advantage of the high sensibility, precision, and accuracy of ICP-MS measurements. In the Neolithic site of Mas d'Is (Alacant, Spain), we have applied REE analysis in a huge stratigraphic sequence called Pit 6, which was known to contain a large anthropogenic component. Randomly collected soil samples were sequentially taken in order to identify anthropogenic soil formations and to prove the proposed method blind testing has been used. In the specific case of Mas d'Is excavation a recurring question is whether paleosols are at the origin of the human occupation of the sites or it was the occupation of this areas which triggered the paleosols development. Our purpose was to distinguish the degree of human contribution to paleosols formation between samples sequentially taken at few centimeters of distances in a giant stratigraphic sequence (Pit 6) employing REE analysis.
\end{abstract}

\section{Introduction}

Neolithic site of Mas d'Is (Alacant, Spain) and its hinterland (Figure 1) has led us to face some problems about the interaction of anthropogenic and natural processes [1]. At Mas d'Is we have discovered huge Neolithic stratigraphic sequences $>5$ meters that are not at all common in western Mediterranean for an open-air site [2] or elsewhere for the filling of some previously excavated features. New methodological proposals that can contribute to a better understanding of some sedimentological problems in this archaeological site have been tested. We have successfully applied lanthanides (rare earth elements "REE") analysis to distinguish anthropogenic from natural stratigraphic units in predefined classes [1]. The potential of REE to distinguish anthropogenic versus natural sediments was useful in Mas d'Is case, where other wellknown methodologies (sedimentology, microsedimentology, and petrography) fail in discriminating between human and natural soils [1]. In this study we have applied REE analysis in one of those huge stratigraphic sequences called Pit 6.
Randomly collected soil samples were sequentially taken in order to identify anthropogenic soil formations and to prove the proposed method blind testing has been used.

Recently, many studies have concentrated their attention in different environments to know how human activity is recorded in soil formation. Major and trace elements chemical analysis has a long standing application in archaeology [36]. Multielemental soil analysis has been employed as a tool of geochemical prospecting [7-10] and to support interpretation of past workplaces and activity spaces around and within archaeological structures $[11,12]$. In the last three decades REE soil analysis has started to be part of archaeometric studies. It is the strong partition of rear earth elements into the mineral particulate phase, their coherent behavior during weathering, erosion and fluvial transportation, and their high resistance to chemical mobilization [13-16] which underlie the use of REE in sediments as provenance indicators in geochemical studies for some time now [17-22]. Due to their peculiar characteristics, there have been several attempts to 
apply REE soil analysis to different archaeological scenarios [23-26].

At the Mas d'Is, to test our methodological approach we have analyzed 15 soil samples. REE were measured using inductively coupled plasma mass spectrometry (ICP-MS). The multielement capabilities, high sensibility, precision, and accuracy of ICP-MS have been exploited to evaluate variations on REE between our samples. In the specific case of Mas d'Is excavation a recurring question is whether paleosols are at the origin of the human occupation of the sites or it was the occupation of this areas which triggered the paleosols development. Our purpose was to distinguish the degree of human contribution to paleosols formation between samples sequentially taken at few centimeters of distances in a giant stratigraphic sequence (Pit 6) employing REE analysis.

\section{Material and Method}

2.1. Geographical and Archaeological Background. The samples were collected on Mas d'Is archaeological site located in the mountainous inland area of the northernmost Alacant province (Figure 1), within Penàguila headwaters, one of the main Serpis tributaries. The area where the site is located is an old platform where heavy erosion processes have led to a series of deep ravines. Holocene landscape development appears to have progressed from a period of stability to slope denudation with aggradation (stream infilling) followed by rapid incision which initiated sometime near the time of occupation-in fact. Some structures of Mas d'Is are eroded by ravines, which confirms that some incision process occurs after early Neolithic occupation (ca. 5600-4800 cal. BC). The result is a series of deep canyons cut by interfluves receiving the distinctive name of Les Puntes, one of which houses the Neolithic site of Mas d'Is. The current profile is the result of ongoing agricultural changes that ultimately have levelled the previous agricultural terracing topography masking and destroying much of the close-to-surface archaeological record.

The sedimentological environment at Penàguila valley can be characterized as follows: on top of the bedrock, very homogenous beds of Miocene marls and almost 1000 meters thick a set of sediments ranging from weathered marls to alluvial deposits. Those alluvial deposits are framed by the development of important paleosols predating the Neolithic occupation of the site. Around ca. $5600 \mathrm{cal}$. BC, the first farmers appear at Mas d'Is, on the top of one of these paleosols.

Archaeological investigations, beginning at the end of 19th century, have identified an important number of human sites dated to the Early and Middle Holocene. More recently, extensive surveys and excavations of Neolithic villages have provided more detailed information about human settlements in the Alcoi valley. Currently, we have documented more than 100 Neolithic open-air sites that almost without exception are related to paleosols.

The excavated area at Mas d'Is provides different kinds of structures and archaeological materials that chronologically span between the very first Neolithic in the region (ca.

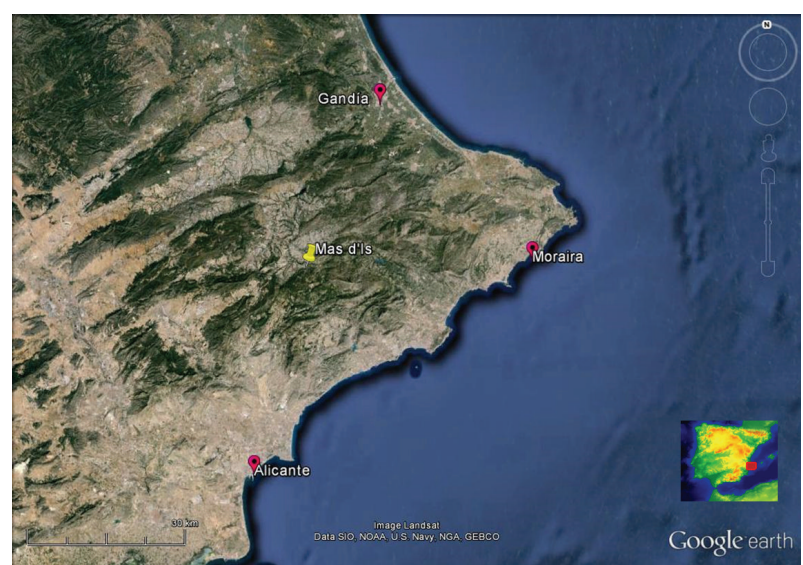

FIGURE 1: Location of the upper and middle Serpis Valley.

$5600 \mathrm{cal}$. B.C.) and present times. The space occupied by the Neolithic site has been an agricultural plot since the Early Neolithic. In the sixth millennium cal BC the site could be divided in two main areas: the village, where the domestic features (houses, hearths, and mills) are found [27] and the area of the ditches, over $150 \mathrm{~m}$ east. Some ditches have an important sequence of infilling sediments, covering more than one millennium (from ca. 5600-4000 cal. BC). On the top, a disturbed layer of Bronze Age ends the archaeological occupation of this area [1]. Pit 6 is one of these features.

2.2. The Samples. Fifteen samples (M1-M15) were collected (Figures 2-3) and were analyzed by ICP-MS (Table 1). Some samples (M1-M12) were taken from the button to the top in Pit 6 (Table 1 and Figures 2 and 3). Sample M1 was collected, $12 \mathrm{cms}$ above the bad rock. This is apparently clayey silt with some organic content to judge by its color (dark gray). Sample M2 was taken $12 \mathrm{cms}$ above M1. It is composed by darkcolored clayey silt with some gravel intrusions. Sample M3 was taken $10 \mathrm{cms}$ above M2 and it is formed by mudstones intrusion with very dark color. Sample M4 was taken $25 \mathrm{cms}$ above M3 and it is composed of a bundle of gray silt with gravel intrusions. Sample M5 was collected $15 \mathrm{cms}$ above M4 and it is composed by a horizontal band above clayey silt with high organic content judging by its dark color. Sample M6 is located $10 \mathrm{cms}$ above M5 and it is composed of a package of clear silt, with abundant intrusions of loam blocks, and appears to have been originated from a loosening of Pit 6 walls. The sample M7 was collected $45 \mathrm{cms}$ above M6 and it is composed of a package of dark silt with somewhat of organic matter. Sample M8 is situated $70 \mathrm{cms}$ above M7, a package of dark silts that may correspond to one of the paleosols documented filling this gap. Sample M9 was taken $40 \mathrm{cms}$ above M8 and is composed of a package of silt with little intrusion.

Sample M10 (UE104355) was located $25 \mathrm{cms}$ above M9. This sample is composed of a darkish silt package that seems to correspond to a deposition period. In this stratigraphic unit (UE104355) a large core of flint was found indicating that this sample was collected in a unit where anthropogenic 


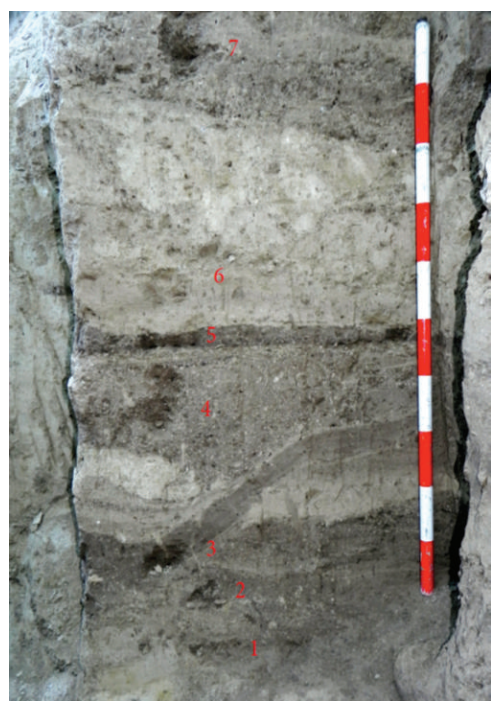

Figure 2: Profile of Foso 6 infilling layers at the Mas d'Is. Location of samples (M1-M7).

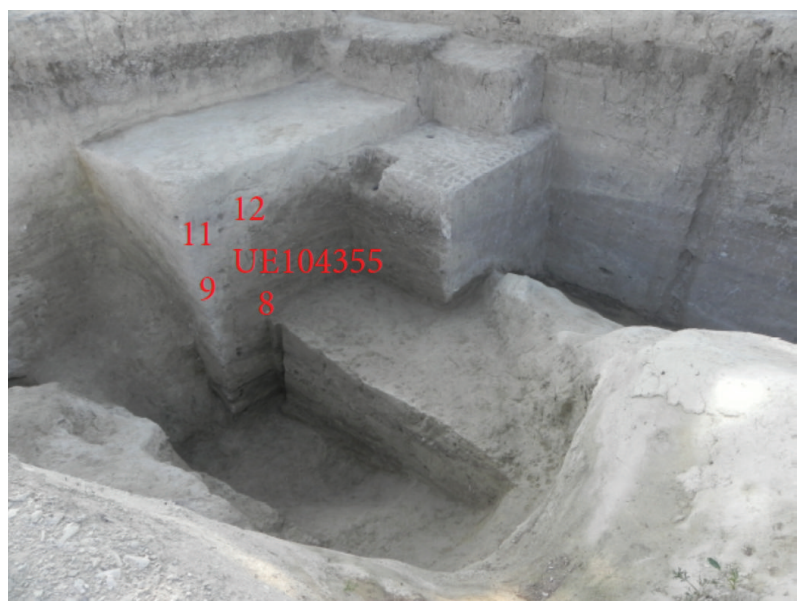

FIgUre 3: Profile of Foso 6 infilling layers at the Mas d'Is. Location of samples (M8-M12). Sample M10 (UE104355).

components are present. Sample M11 was collected $75 \mathrm{cms}$ above sample M10 and is formed by a clear silt package that interposes a well-documented paleosol. Sample M12, $20 \mathrm{cms}$ above the previous M11, is composed of dark silt package that is associated with a paleosol that fills an earlier erosion period dated after the ca. 5000 cal. BC. Sample M13 is marl in contact with the UE104355 (M10). The M14 (marl) has been directly taken from the parent rock. The M15 sample was sampled in the sector BC105 and it is composed by a dark area and silty sediment from the Bronze Age dated by the recovered ceramic fragments.

2.3. Chemical Analysis of Soil. The sampling was carried out collecting the sediments sequentially from Pit 6 stratigraphic wall (Figures 2-3) and not sieved. The 15 samples have been sampled using microspoon spatula made of stainless steel, always cleaned before taking a new sample, and stored in
$15 \mathrm{~mL}$ test tubes. Sample preparation and digestion have been carried out as described by Gallello et al. [1]. The process includes a thermal treatment at $450^{\circ} \mathrm{C}$. Successively the samples were crushed and homogenized employing an agate mortar. A partial soil analysis has been carried out and we have developed a digestion method and a range of dilutions from the digested solution in order to provide reproducible and comparable results compatible with the sensitivity of the analytical method employed.

The digestion method consisted of the addition of $1.5 \mathrm{~mL} \mathrm{HCl}$ and $1.5 \mathrm{~mL} \mathrm{HNO}_{3}$ to $0.5 \mathrm{~g}$ of sample in glass tubes placing them in a water bath at $100^{\circ} \mathrm{C}$ for $40 \mathrm{~min}$. In addition, two blanks were prepared using the same acid volumes and digestion conditions of the samples. Subsequently, the digested solutions have been carefully poured into plastic tubes of $15 \mathrm{~mL}$, bringing the volume to $15 \mathrm{~mL}$ with purified water. This concentrated solution (A) was diluted $1: 10$ obtaining a solution (B) to measure La, Ce, Pr, Nd, Sm, Eu, Gd, $\mathrm{Tb}, \mathrm{Dy}, \mathrm{Ho}, \mathrm{Er}, \mathrm{Tm}, \mathrm{Yb}, \mathrm{Lu}, \mathrm{Sc}$, and Y. Dilution containing $10 \%$ concentrated $\mathrm{HCl}$ and $10 \%$ concentrated $\mathrm{HNO}_{3}$ has been maintained in all solutions. A multielemental stock solution containing REE, Sc, and Y at concentration of $100 \mu \mathrm{g} / \mathrm{mL}$ was prepared. The calibration standards were prepared employing $50 \mathrm{~mL}$ volumetric flasks and adding $5 \mathrm{~mL} \mathrm{HCl}+5 \mathrm{~mL} \mathrm{HNO}_{3}$ plus the corresponding volume of standard solution and filling up to volume with pure water. Solutions were analyzed by ICP-MS with Perkin Elmer Elan DRCII (Concord, Ontario, Canada). To avoid the obstruction of the nebulizer system the sample was filtered employing filter paper (Whatman N.1 of $70 \mathrm{~mm}$ ). Concentrations ranging between 0 and $0.6 \mu \mathrm{g} / \mathrm{mL}$ have been used for $\mathrm{La}, \mathrm{Ce}, \mathrm{Pr}$, and $\mathrm{Nd}$ and concentrations ranging between 0 and $0.1 \mu \mathrm{g} / \mathrm{mL}$ for $\mathrm{Sm}, \mathrm{Eu}, \mathrm{Gd}, \mathrm{Tb}, \mathrm{Dy}$, Ho, Er, Tm, Yb, and Lu. All standards were acquired from Sharlab S.L. (Barcelona). The standard error of readings during the analysis ranged from 3\% to 9\% for REE. Soil GBW07408 has been used as standard reference material for evaluating the analytical method. Rh was used as internal standard. REE concentrations were normalized to Post-Archaean Australian Shales (PAAS) concentrations using the values of Taylor and McLennan [28].

\section{Results and Discussion}

3.1. Composition of Samples. 15 samples have been analyzed by ICP-MS to determine REE, Sc, and Y contents. The analyzed isotopes, instrumental LOD and LOQ, and $R^{2}$ are listed in Table 2. The results expressed in $\mu \mathrm{g} / \mathrm{g}$ are shown in Table 3 . The samples (from M1 to M12) have been sequentially collected from the bottom to the top in Pit 6 (Figures 2 and 3). The sample M13 is marl situated in contact to UE104355 where the sample M10 was taken. The sample M14 is marl belonging to another excavation sector. Also the sample M15 belongs to an archaeological stratigraphy located in a different excavation sector dated in bronze age (BC105). Observing the results (Table 3) M1 contains the lowest values of $\mathrm{La}, \mathrm{Ce}, \mathrm{Nd}, \mathrm{Eu}, \mathrm{Tm}, \mathrm{Yb}, \mathrm{Sc}$, and Y between the samples. Gradually REE values arise sequentially between M2, M3, and M4. Samples M5, M6, M7, M8, and M9 maintain lanthanides 
TABLE 1: A total of 15 samples (M1-M15) were analysed. Stratigraphic Unit (SU). Centimeters of distance between the samples (cms).

\begin{tabular}{|c|c|c|c|c|c|}
\hline SAMPLE & ZONE & SU & CRONOLOGY & ANALYSIS & $\mathrm{Cms}$ \\
\hline M1 & PIT 6 & - & - & REE & 12 \\
\hline M2 & PIT 6 & - & - & REE & 22 \\
\hline M3 & PIT 6 & - & - & REE & 33 \\
\hline M4 & PIT 6 & - & - & REE & 58 \\
\hline M5 & PIT 6 & - & - & REE & 73 \\
\hline M6 & PIT 6 & - & - & REE & 83 \\
\hline M7 & PIT 6 & - & - & REE & 128 \\
\hline M8 & PIT 6 & - & - & REE & 198 \\
\hline M9 & PIT 6 & - & - & REE & 238 \\
\hline M10 & PIT 6 & 104355 & - & REE & 263 \\
\hline M11 & PIT 6 & - & - & REE & 338 \\
\hline M12 & PIT 6 & - & $>5000 \mathrm{cal} \mathrm{BC}$ & REE & 358 \\
\hline M13 & PIT 6 & Bedrock & Tertiary & REE & - \\
\hline M14 & $\mathrm{C}$ & Bedrock & Tertiary & REE & - \\
\hline M15 & BC105 & - & Bronze & REE & - \\
\hline
\end{tabular}

TABLE 2: ICP-MS analysis. Mass. Detection limits (LOD), quantification limits (LOQ), and $R^{2}$.

\begin{tabular}{lcccc}
\hline Elements & $\begin{array}{c}\text { Mass } \\
{[\mathrm{Da}]}\end{array}$ & LOD & LOQ & $R^{2}$ \\
\hline $\mathrm{La}$ & 139 & 0.0004 & 0.0014 & 0.9997 \\
$\mathrm{Ce}$ & 140 & 0.0005 & 0.0018 & 0.9997 \\
$\mathrm{Pr}$ & 141 & 0.00010 & 0.0003 & 0.9997 \\
$\mathrm{Nd}$ & 142 & 0.0003 & 0.0001 & 0.9985 \\
$\mathrm{Sm}$ & 152 & 0.0003 & 0.0011 & 0.9999 \\
$\mathrm{Eu}$ & 151 & $5 E-05$ & 0.00018 & 0.9998 \\
$\mathrm{Gd}$ & 158 & 0.00015 & 0.0005 & 0.9998 \\
$\mathrm{~Tb}$ & 159 & $5 E-05$ & 0.00017 & 0.9977 \\
$\mathrm{Dy}$ & 162 & $1.1 E-05$ & $4 E-05$ & 0.9998 \\
$\mathrm{Ho}$ & 165 & $3 E-05$ & 0.00011 & 0.9983 \\
$\mathrm{Er}$ & 166 & 0.00013 & 0.0004 & 0.9999 \\
$\mathrm{Tm}$ & 169 & $1.6 E-05$ & $5 E-05$ & 0.9985 \\
$\mathrm{Yb}$ & 172 & $7 E-05$ & 0.0002 & 0.9999 \\
$\mathrm{Lu}$ & 175 & $1.7 E-05$ & $6 E-05$ & 0.9991 \\
$\mathrm{Sc}$ & 45 & 0.013 & 0.04 & 0.9998 \\
$\mathrm{Y}$ & 89 & 0.0005 & 0.0016 & 0.9996 \\
$\mathrm{Rh}$ & 103 & & & \\
\hline
\end{tabular}

Note: Instrumental LOD and LOQ. ${ }^{*}$ Internal standard.

concentrations similar to M2. Sample M10 belonging to UE104355 is, throughout the sequence, the richest unit in archaeological materials and shows the highest REE values. The sample M13 (marl) also shows REE values slightly lower than M10 probably due to the relation between this marl and UE104355 already mentioned. Samples M11 and M12 are the latest belonging to the sequence and show low REE concentrations in relation to the rest of samples except M1 which maintains the lowest levels. Sample M14 (marl) belongs to an excavation area far from Pit 6. REE values in this sample
(M14) are in general similar to the sequence samples which contain the lowest values. Sample M15 dated in Bronze Age was taken in another excavation sector (BC105); this sample contains REE values that are similar to the average of the sequence (M1-M12). Finally the sequence sampled in Pit 6 reveals that the anthropogenic units (M10) and the directly related deposits (M13) show a REE enrichment.

3.2. Relation of REE/REE $E_{\text {PAAS }}$ Ratios La/Yb $\mathrm{Y}_{\mathrm{PAAS}}, \mathrm{La} / \mathrm{Gd}_{\mathrm{PAAS}}$

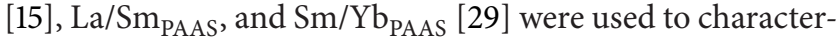
ize the REE/PAAS profiles in terms of relative enrichment or depletion of light REE (La-Nd), medium REE (Sm-Ho), and heavy REE (Er-Lu).

Table 4 shows differences in $\mathrm{La} / \mathrm{Yb}_{\text {PAAS }}, \mathrm{La} / \mathrm{Gd}_{\text {PAAS }}, \mathrm{La} /$ $\mathrm{Sm}_{\mathrm{PAAS}}$, and $\mathrm{Sm} / \mathrm{Yb}_{\mathrm{PAAS}}$ ratio between the samples similar to those observed in Table 3. M1 contains the lowest values of $\mathrm{La} / \mathrm{Yb}_{\text {PAAS }}, \mathrm{La} / \mathrm{Gd}_{\text {PAAS }}, \mathrm{La} / \mathrm{Sm}_{\mathrm{PAAS}}$, and $\mathrm{Sm} / \mathrm{Yb}_{\text {PAAS }}$. Those values arise gradually trough the samples M2, M3, and M4. Samples M5, M6, M7, M8, and M9 show values similar to M2. The sample M10 (UE104355), rich in archaeological materials, presents again the highest $\mathrm{La} / \mathrm{Yb}_{\text {PAAS }}, \mathrm{La} / \mathrm{Gd}_{\text {PAAS }}, \mathrm{La} / \mathrm{Sm}_{\text {PAAS }}$, and $\mathrm{Sm} / \mathrm{Yb}_{\text {PAAS }}$ values. Sample 13 (marl) related to M10 shows values slightly lower than M10. Samples M11 and M12 are the latest belonging to the sequence and show lower REE concentrations in relation to the rest of samples except M1 which maintains the lowest levels. Sample M14 (marl) values are in general similar to the sequence samples which contain the lowest values. Sample M15 (Bronze Age) contains again values similar to the average of the sequence (M1-M12).

Summing up, M10 contains the highest values of $\mathrm{La} / \mathrm{Yb}_{\text {PAAS }}, \mathrm{La} / \mathrm{Gd}_{\text {PAAS }}, \mathrm{La} / \mathrm{Sm}_{\text {PAAS }}$, and $\mathrm{Sm} / \mathrm{Yb}_{\text {PAAS }}$ and a mayor enrichment of the sequence (M1-M12). A moderate reduction in LREE, MREEs, and HREE can be observed for the intermediate samples of the sequence (M2-M3-M4-M5M6-M7-M8-M9-M11). A mayor reduction in LREE, MREE, and HREE can be observed at the edge of the sequence, at the bottom (M1), and at the top (M12). Probably this 


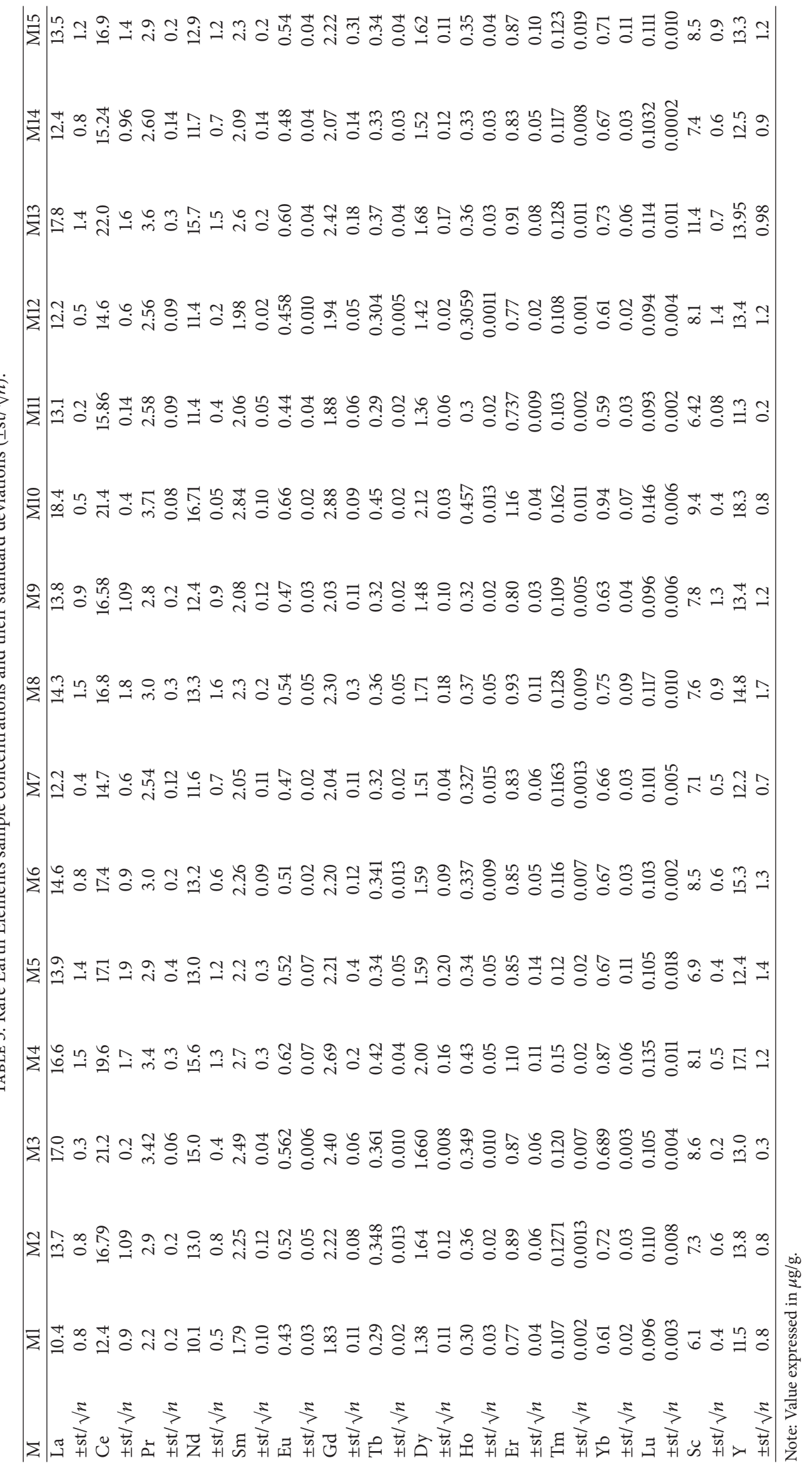


TABLE 4: $\mathrm{La} / \mathrm{Yb}_{\text {PAAS }}, \mathrm{La} / \mathrm{Gd}_{\text {PAAS }}, \mathrm{La} / \mathrm{Sm}_{\text {PAAS }}, \mathrm{Sm} / \mathrm{Yb}_{\text {PAAS }}\left(\mathrm{REE}\right.$ values normalized to $\left.\mathrm{REE}_{\mathrm{PAAS}}\right)$ and their standard deviations $( \pm$ st $/ \sqrt{ } n)$.

\begin{tabular}{|c|c|c|c|c|c|c|c|c|}
\hline SAMPLES & $\mathrm{La} / \mathrm{Yb}_{\text {PAAS }}$ & $\pm \mathrm{st} / \sqrt{ } n$ & $\mathrm{La} / \mathrm{Gd}_{\text {PAAS }}$ & $\pm \mathrm{st} / \sqrt{ } n$ & $\mathrm{La} / \mathrm{Sm}_{\text {PAAS }}$ & $\pm s t / \sqrt{ } n$ & $\mathrm{Sm} / \mathrm{Yb}_{\mathrm{PAAS}}$ & $\pm \mathrm{st} / \sqrt{ } n$ \\
\hline M1 & 3.7 & 0.3 & 2.2 & 0.2 & 1.9 & 0.14 & 0.63 & 0.04 \\
\hline M2 & 4.8 & 0.3 & 2.9 & 0.2 & 2.5 & 0.15 & 0.80 & 0.04 \\
\hline M3 & 6.031 & 0.10 & 3.65 & 0.06 & 3.06 & 0.05 & 0.88 & 0.02 \\
\hline M4 & 5.9 & 0.5 & 3.6 & 0.3 & 3.0 & 0.3 & 0.95 & 0.09 \\
\hline M5 & 4.9 & 0.5 & 3.0 & 0.3 & 2.5 & 0.3 & 0.80 & 0.09 \\
\hline M6 & 5.2 & 0.3 & 3.1 & 0.2 & 2.63 & 0.15 & 0.80 & 0.03 \\
\hline M7 & 4.3 & 0.2 & 2.62 & 0.09 & 2.20 & 0.08 & 0.73 & 0.04 \\
\hline M8 & 5.1 & 0.5 & 3.1 & 0.3 & 2.57 & 0.3 & 0.82 & 0.07 \\
\hline M9 & 4.9 & 0.3 & 2.96 & 0.18 & 2.48 & 0.15 & 0.74 & 0.04 \\
\hline M10 & 6.5 & 0.2 & 3.94 & 0.12 & 3.307 & 0.10 & 1.01 & 0.04 \\
\hline M11 & 4.66 & 0.09 & 2.82 & 0.05 & 2.37 & 0.04 & 0.73 & 0.02 \\
\hline M12 & 4.3 & 0.2 & 2.61 & 0.11 & 2.19 & 0.09 & 0.701 & 0.008 \\
\hline M13 & 6.3 & 0.5 & 3.8 & 0.3 & 3.2 & 0.2 & 0.92 & 0.09 \\
\hline M14 & 4.4 & 0.3 & 2.7 & 0.2 & 2.24 & 0.15 & 0.74 & 0.05 \\
\hline M15 & 4.8 & 0.4 & 2.9 & 0.3 & 2.4 & 0.2 & 0.81 & 0.08 \\
\hline
\end{tabular}

happens because the depreciation of the filling of the Pit 6 was produced with materials similar to the baseline once the area ceased to be regularly occupied by Neolithic groups. Therefore the enrichment in REE seems to be related to stratigraphic units with a mayor anthropogenic activity. On the other hand a reduction in LREE, MREE, and HREE is detected in units with less human presence. The REE analysis of samples taken sequentially can be a useful tool to identify stratigraphic area with mayor anthropogenic impact and define the impact area of taphonomic environment. Furthermore those REE features are not clearly reproduced by mayor elements $(\mathrm{Ca}$ and $\mathrm{Mg}$ ) and trace elements values in the studied samples (supplemental table, available online at http://dx.doi.org/10.1155/2014/767085), most likely due to their unintelligible, unknown, and unpredictable natural activities in the studied context.

3.3. $\mathrm{Ce}$ and $\mathrm{Eu}$ Anomalies. $\mathrm{Ce}^{*}$ and $\mathrm{Eu}^{*}$ anomalies are calculated as a ratio of normalized measured concentrations from the sample [30]:

$$
\begin{aligned}
& \mathrm{Ce}^{*}=(\mathrm{Ce} / \mathrm{Ce} s) /(1 / 2 \mathrm{La} / \mathrm{La} s+1 / 2 \mathrm{Pr} / \mathrm{Pr} s)-1, \\
& \mathrm{Eu}^{*}=(\mathrm{Eu} / \mathrm{Eus}) /(1 / 2 \mathrm{Sm} / \mathrm{Sm} s+1 / 2 \mathrm{Gd} / \mathrm{Gd} s)-1 .
\end{aligned}
$$

The "*" and the $s$ subscript denote the anomaly and the concentration of standard Post-Archean Australian Shale (PAAS).

In this set of samples $\mathrm{Eu}^{*}$ and $\mathrm{Ce}^{*}$ values are less than one (Figure 4) and show a strong negative europium anomaly and cerium negative anomaly. That could point to more reducing conditions, without oxygen access in the archaeological site, proving stability in the studied stratigraphic units. The same $\mathrm{Eu}^{*}$ and $\mathrm{Ce}^{*}$ results have been previously obtained at the same site [1].

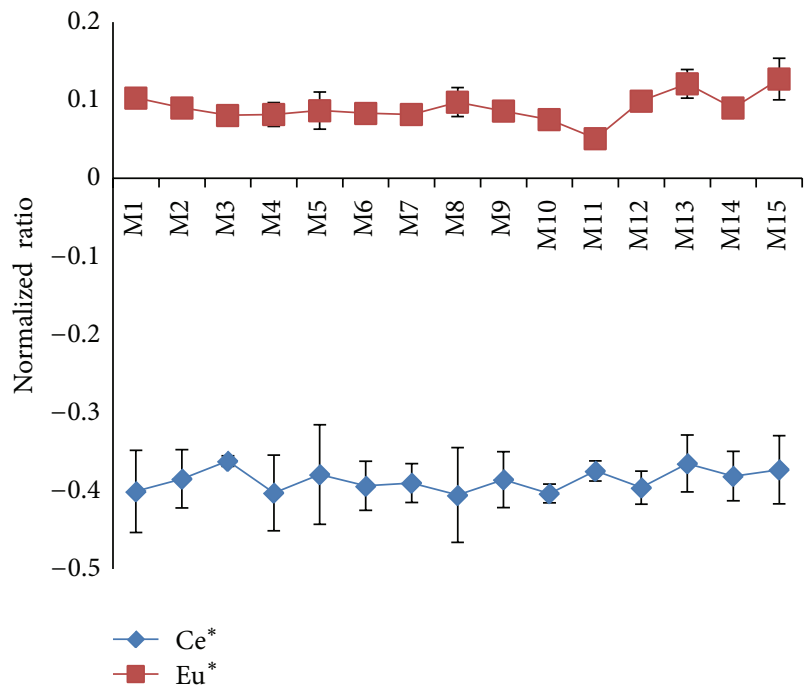

FIGURE 4: $\mathrm{Ce}^{*}$ and $\mathrm{Eu}^{*}$ anomalies; normalized ratio $<1$ in samples (M1-M15) and their standard deviations.

\section{Conclusion}

ICP-MS analysis has shown to be an effective technique to observe objective internal relation between samples to test our hypotheses. We consider that REE analyses are useful to identify anthropogenic patterns due to the particular chemical characteristics of those elements. Our data show that REE may be good discriminators when there are not only important, but also hidden differences between stratigraphic units. The results of samples sequentially taken in Pit 6 have revealed that the sample M10 (UE104355) contains the greatest enrichment in REE of the entire sequence (M1M12) and confirm the anthropogenic origin of this unit. A moderate reduction in LREE, MREE, and HREE values can 
be observed in intermediate samples of the sequence (M2M3-M4-M5-M6-M7-M8-M9-M11). A reduction of values on the edge of the sequence (bottom sample M1 and top sample M12) may reflect the natural origin of these units. Analysis of samples taken sequentially in a huge section (Pit 6) shows that rare earth elements may help to identify areas influenced by a higher human impact and to define the degree of anthropization on the environment also in a range of few centimetres.

Poor preservation of ancient remains in archaeological stratigraphy could carry uncertainty to identify anthropogenic traces. REE analysis can indicate whether the formation of soil is due to human activities or natural processes. Many techniques may be able to shed light on ancient human group activities, but we are confident that the commonly employed methodologies can be enhanced by the use of REE. Our approach allows us to evaluate the degree of human contribution to the formation of paleosols, providing new ways to deal with one of the most classic archaeological problems.

Certainly, more analyses of rare earths are needed to better characterize the composition of the parent rock and to gain more knowledge about the dynamics that take place to differentiate natural and anthropogenic soils, not only in the archaeological area of Mas d'Is but also at regional level.

\section{Conflict of Interests}

The authors declare that there is no conflict of interests regarding the publication of this paper.

\section{References}

[1] G. Gallello, A. Pastor, A. Diez, N. La Roca, and J. Bernabeu, "Anthropogenic units fingerprinted by REE in archaeological stratigraphy: mas d'Is (Spain) case," Journal of Archaeological Science, vol. 40, no. 2, pp. 799-809, 2013.

[2] J. Bernabeu, L. L. Molina, A. Díez Castillo, and T. Orozco Köhler, "Inequalities and power. Three millenia of prehistory in Mediterranean Spain (5600-2000 cal BC)," in Social Inequality in Iberian Late Prehistory, P. Diaz-del-Río and L. García Sanjuán, Eds., vol. 1525 of British Archaeological Reports, pp. 97116, 2006

[3] J. A. Entwistle and P. W. Abrahams, "Multi-element analysis of soils and sediments from Scottish historical sites: the potential of inductively coupled plasma-mass spectrometry for rapid site investigation," Journal of Archaeological Science, vol. 24, no. 5, pp. 407-416, 1997.

[4] J. A. Entwistle, P. W. Abrahams, and R. A. Dodgshon, "Multielement analysis of soils from Scottish historical sites. Interpreting land-use history through the physical and geochemical analysis of soil," Journal of Archaeological Science, vol. 25, no. 1, pp. 53-68, 1998.

[5] L. Barba and A. Ortiz, "Análisis químico de pisos de ocupación: un caso etnográfico en Tlaxcala, Mexico," Latin American Antiquity, vol. 3, pp. 63-82, 1992.

[6] L. Barba, F. Pierrebourg, C. Trejo, A. Ortiz, and K. Link, “ Activities humaines refletées dans les sols d'unites d'habitation contemporaine et Prehispanique du Yucatan, Mexico: Etudes chimiques, ethonoarcheologiques et archeologiques," Revue d'Archeometrie, vol. 19, pp. 79-95, 1995.

[7] M. A. Aston, M. H. Martin, and A. W. Jackson, "The use of heavy metal soil analysis for archaeological surveying," Chemosphere, vol. 37, no. 3, pp. 465-477, 1998.

[8] J. L. Bintliff, B. Davies, C. Gaffney, A. Snodgrass, and A. Waters, "Trace metal accumulations in soils on and around ancient settlements in Greece," in Geoprospection in the Archaeological Landscape, vol. 17 of Oxbow Monographs, pp. 9-24, Oxbow Books, Oxford, UK, 1992.

[9] W. P. Eckel, M. B. Rabinowitz, and G. D. Foster, "Investigation of unrecognized former secondary lead smelting sites: confirmation by historical sources and elemental ratios in soil," Environmental Pollution, vol. 117, no. 2, pp. 273-279, 2002.

[10] D. R. Schlezinger and B. L. Howes, "Organic phosphorus and elemental ratios as indicators of prehistoric human occupation," Journal of Archaeological Science, vol. 27, no. 6, pp. 479-492, 2000.

[11] F. G. Fernández, R. E. Terry, T. Inomata, and M. Eberl, "An ethnoarchaeological study of chemical residues in the floors and soils of Q'eqchi' Maya Houses at Las Pozas, Guatemala," Geoarchaeology, vol. 17, no. 6, pp. 487-519, 2002.

[12] C. A. Wilson, D. A. Davidson, and M. S. Cresser, "Multielement soil analysis: an assessment of its potential as an aid to archaeological interpretation," Journal of Archaeological Science, vol. 35, no. 2, pp. 412-424, 2008.

[13] S. M. McLennan, "Rare earth elements in sedimentary rocks: influence of provenance and sedimentary processes," in Geochemistry and Mineralogy of Rare Earth Elements, B. R. Lipin and G. A. McKay, Eds., vol. 21 of Reviews in Mineralogy, Mineralogical Society of America, Washington, DC, USA, 1992.

[14] S. M. McLennan and S. R. Taylor, "Rare earth elements in sedimentary rocks, granites and uranium deposits of the Pine Creek geosyncline," in Uranium in the Pine Creek Geosynclines, J. Ferguson and A. B. Coleby, Eds., pp. 175-190, IAEA, Vienna, Austria, 1980.

[15] N. C. Munksgaard, K. Lim, and D. L. Parry, "Rare earth elements as provenance indicators in North Australian estuarine and coastal marine sediments," Estuarine, Coastal and Shelf Science, vol. 57, no. 3, pp. 399-409, 2003.

[16] Z. Jin, F. Li, J. Cao, S. Wang, and J. Yu, "Geochemistry of Daihai Lake sediments, Inner Mongolia, North China: implications for provenance, sedimentary sorting, and catchment weathering," Geomorphology, vol. 80, no. 3-4, pp. 147-163, 2006.

[17] L. Arenas, M. Ortega, M. J. García-Martínez, E. Querol, and J. F. Llamas, "Geochemical characterization of the mining district of Linares (Jaen, Spain) by means of XRF and ICP-AES," Journal of Geochemical Exploration, vol. 108, no. 1, pp. 21-26, 2011.

[18] A. Bellanca, D. Masetti, and R. Neri, "Rare earth elements in limestone/marlstone couplets from the Albian-Cenomanian Cismon section (Venetian region, northern Italy): assessing REE sensitivity to environmental changes," Chemical Geology, vol. 141, no. 3-4, pp. 141-152, 1997.

[19] G. T. Klaver and T. C. E. van Weering, "Rare Earth Element fractionation by selective sediment dispersal in surface sediments: the Skagerrak," Marine Geology, vol. 111, no. 3-4, pp. 345-359, 1993.

[20] H. Liu, F. Prugnolle, A. Manica, and F. Balloux, "A geographically explicit genetic model of worldwide human-settlement history," The American Journal of Human Genetics, vol. 79, no. 2, pp. 230-237, 2006. 
[21] B. Markert and Z. de Li, "Natural background concentrations of rare-earth elements in a forest ecosystem," Science of the Total Environment, vol. 103, no. 1, pp. 27-35, 1991.

[22] H. Vital and K. Stattegger, "Composition and trace-element geochemistry of detrital clay and heavy-mineral suites of the lowermost amazon river: a provenance study, Journal of Sedimentary Research, vol. 69, no. 3, pp. 563-575, 1999.

[23] D. E. Cook, B. Kovacevich, T. Beach, and R. Bishop, "Deciphering the inorganic chemical record of ancient human activity using ICP-MS: a reconnaissance study of late Classic soil floors at Cancuén, Guatemala," Journal of Archaeological Science, vol. 33, no. 5, pp. 628-640, 2006.

[24] J. A. Entwistle, P. W. Abrahams, and R. A. Dodgshon, "Multielement analysis of soils from Scottish historical sites. Interpreting land-use history through the physical and geochemical analysis of soil," Journal of Archaeological Science, vol. 25, no. 1, pp. 53-68, 1998.

[25] F. Saiano and R. Scalenghe, "An anthropic soil transformation fingerprinted by REY patterns," Journal of Archaeological Science, vol. 36, no. 11, pp. 2502-2506, 2009.

[26] G. D. Kamenov, M. Brenner, and J. L. Tucker, "Anthropogenic versus natural control on trace element and $\mathrm{Sr}-\mathrm{Nd}-\mathrm{Pb}$ isotope stratigraphy in peat sediments of southeast Florida (USA), 1500 AD to present," Geochimica et Cosmochimica Acta, vol. 73, no. 12, pp. 3549-3567, 2009.

[27] J. Bernabeu, T. Orozco, A. Díez, M. Gómez, and J. F. Molina, "Mas d'Is (Penàguila, Alicante): aldeas y recintos monumentales del Neolítico inicial en el Valle del Serpis," Trabajos de Prehistoria, vol. 60, no. 2, pp. 39-60, 2003.

[28] S. R. Taylor and S. M. McLennan, The Continental Crust: Its Composition and Evolution, Blackwell Scientific, Boston, Mass, USA, 1985.

[29] D. R. Xu, Z. L. Wang, H. Y. Chen et al., "Petrography and geochemistry of the Shilu Fe-Co-Cu ore district, South China: implications for the origin of a Neoproterozoic BIF," Ore Geology Reviews, vol. 57, pp. 322-350, 2014.

[30] E. A. Hinz and M. J. Kohn, "The effect of tissue structure and soil chemistry on trace element uptake in fossils," Geochimica et Cosmochimica Acta, vol. 74, no. 11, pp. 3213-3231, 2010. 

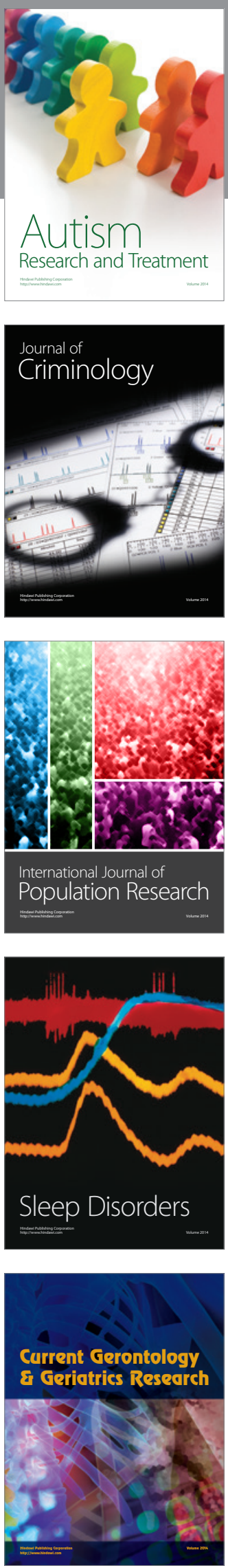
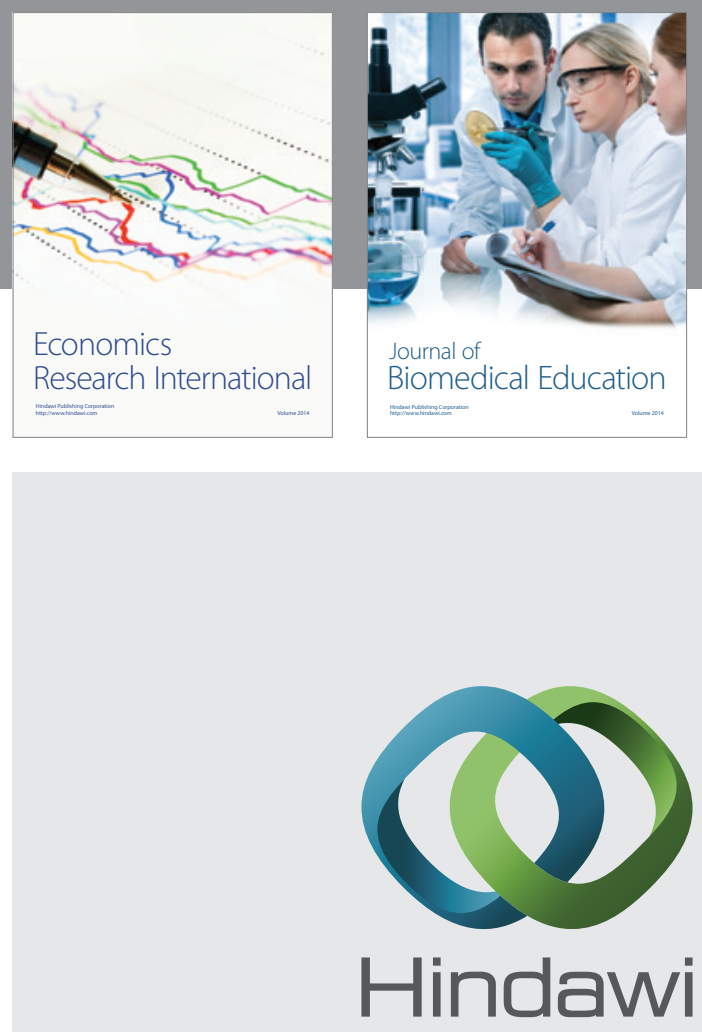

Submit your manuscripts at

http://www.hindawi.com
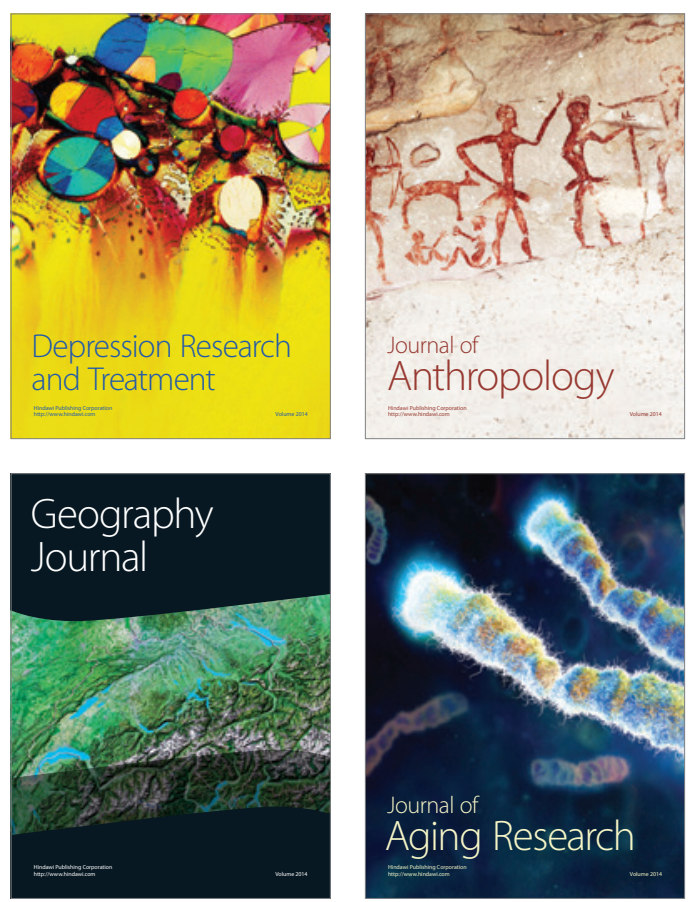
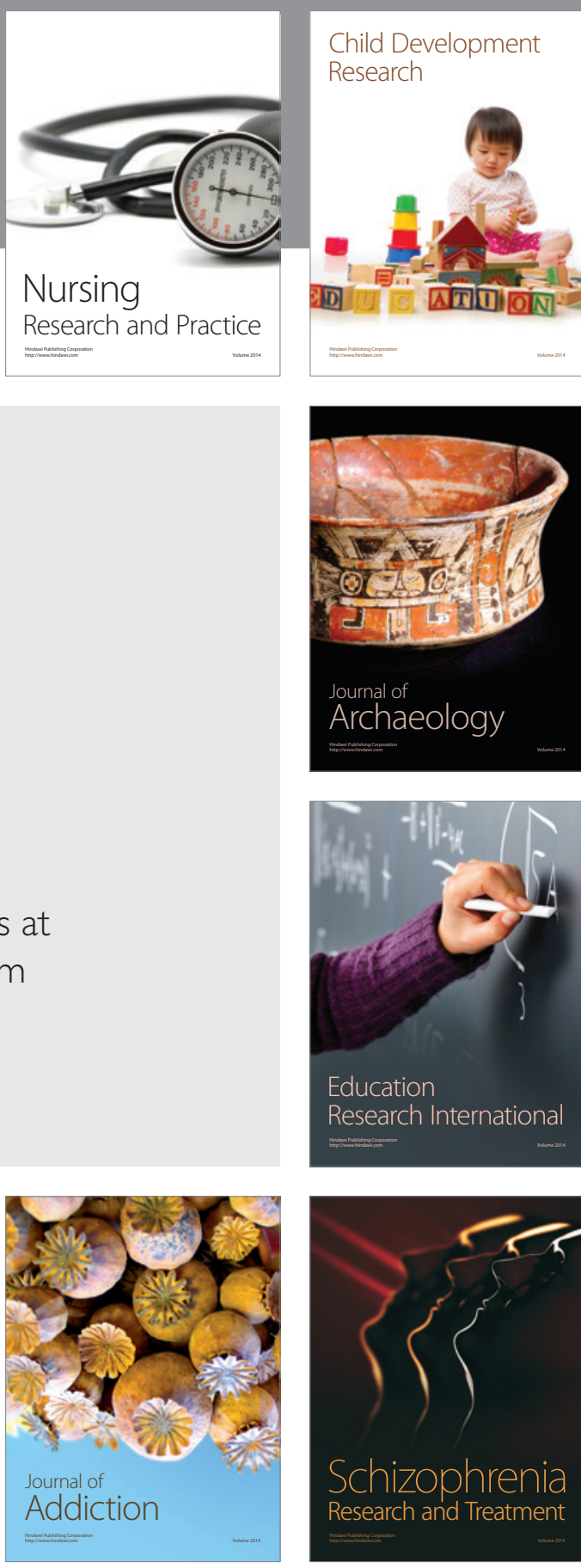

(D)
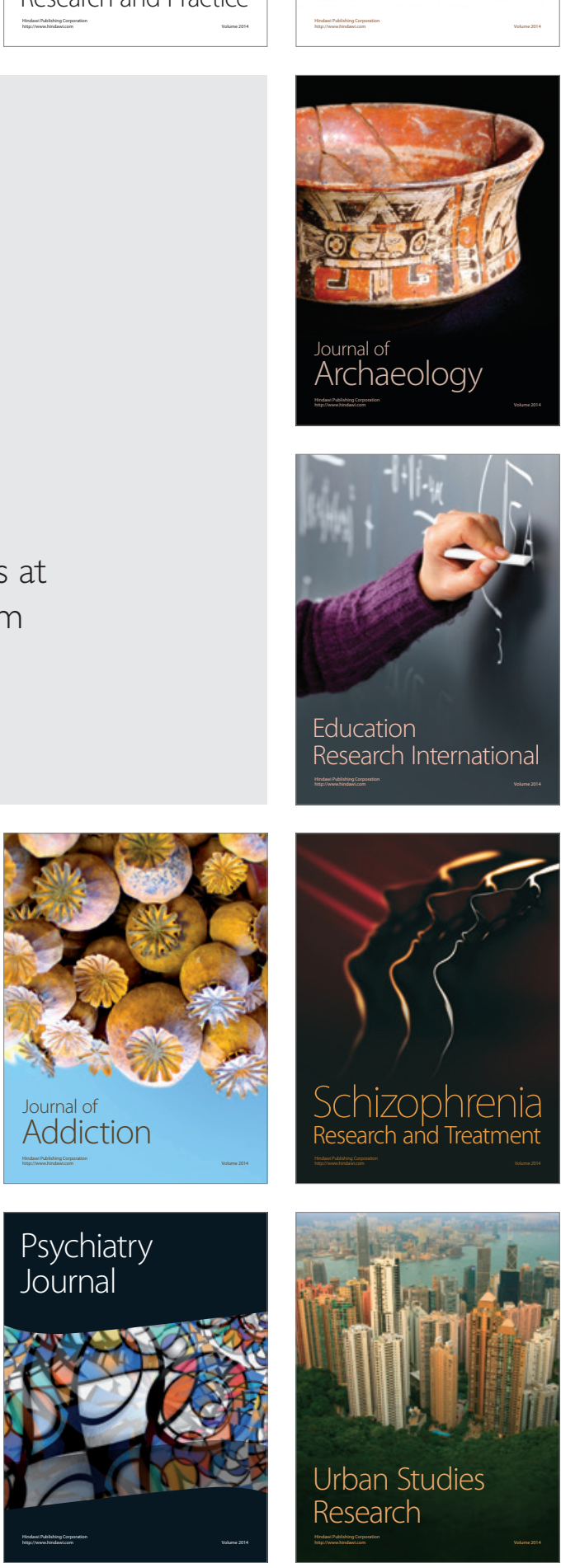